\title{
PERAN PENASEHAT HUKUM DALAM MEMBANTU TERSANGKA PADA PENYIDIKAN GUNA TERCIPTANYA PROSES HUKUM YANG ADIL
}

\author{
Oleh : \\ Asnatuti $^{*}$ \\ Ibrahim *
}

\begin{abstract}
ABSTRAK
KUHAP mengamanatkan bahwa penyidik wajib memberikan kesempatan kepada tersangka, menghubungi dan minta bantuan penasihat hukum untuk mendampinginyasejak penangkapan. Namun ketentuan KUHAP tersebut, dalam praktiknya hampir tidak pernah dilaksanakan. Hal itu terjadi karena adanya kekosongan norma di dalam KUHAP, yang mengatur tentang akibat hukum bagi penyidik dan penyidikan perkara bersangkutan, yang mengabaikan kewajiban dimaksud. Ketiadaan hal itu berpotensi menimbulkan penyalahgunaan kekuasaan oleh penyidik, dengan melakukan kekerasan demi memperoleh keterangan "yang diinginkan" dari seorang tersangka. Tindakan penyidik yang demikian, akan menciderai hakekat penegakan hukum yakni terciptanya proses hukum yang adil (due process of law) sehingga diperlukan Peranan Penasihat Hukum agar terciptanya proses hukum yang adil yakni terciptanya due process of law, yang ditandai dengan proses penyidikan bebas dari intimidasi, kekerasan dan penyiksaan.
\end{abstract}

Kata Kunci: Peran Penasehat Hukum, Proses Hukum, Adil

\section{A. Latar Belakang Masalah}

Indonesia diidealkan dan dicita-citakan oleh the founding fathers sebagai suatu Negara Hukum (Rechsstaat/The Rule of Law).Dalam Pasal 1 ayat (3) UUD 1945, menegaskan bahwa "Negara Indonesia adalah Negara Hukum". Dalam negara hukum, negara mengakui dan melindungi hak asasi manusia setiap individu tanpa membedakan latar belakangnya, sehingga semua orang memiliki hak untuk diperlakukan sama di hadapan hukum (equality before the law). ${ }^{1}$

Persamaan di hadapan hukum harus diartikan secara dinamis dan tidak diartikan secara statis.Artinya, jika ada persamaan di hadapan hukum bagi semua orang, maka harus diimbangi pula dengan persamaan perlakuan (equal treatment) bagi semua orang.

\footnotetext{
* Advokat, Alumni Program Magister Ilmu Hukum Unbari.

* Pengajar Program Magister Ilmu Hukum Unbari.

${ }^{1}$ Adnan Buyung Nasution, Bantuan Hukum, Akses Masyarakat Marginal Terhadap Keadilan (Tinjauan, Sejarah, Konsep, Kebijakan, Penerapan dan Perbandingan di Berbagai Negara), Lembaga Bantuan Hukum Jakarta, 2007, halaman 97.
} 
Adanya prinsip-prinsip persamaan di hadapan hukum dan perlakuan yang adil bagi seluruh masyarakat, merupakan petunjuk bahwa negara wajib memperhatikan masalah bantuan hukum bagi warganya.Penyelenggaraan bantuan hukum yang tidak serius merupakan pelanggaran hak asasi manusia yang berarti bertentangan dengan hak konstitusional warga negara.

Penyelenggaraan bantuan hukum tidak dapat dilepaskan dengan aturan-aturan hukum yang dapat menjamin penegakan hukum.Aturan hukum yang menjamin penyelenggaraan bantuan hukum adalah Kitab Undang-Undang Hukum Acara Pidana (KUHAP) yang telah mengangkat dan menempatkan tersangka dan terdakwa dalam kedudukan yang sederajat sebagai makhluk Tuhan yang memiliki harkat dan kemanusiaan yang utuh. Di samping itu Undang-Undang Nomor 4 Tahun 2004 tentang Kekuasaan Kehakiman khususnya Pasal 37 sampai dengan Pasal 39 juga memberikan perlindungan terhadap setiap orang yang tersangkut perkara berhak untuk memperoleh bantuan hukum melalui advokat dan advokat wajib membantu penyelesaian perkara dengan menjunjung tinggi hukum dan keadilan.

Dalam KUHAP tidak ada perbedaan di hadapan hukum, baik tersangka, terdakwa dan aparat penegak hukum sama-sama warga negara yang sama kedudukannya dan kewajibannya di depan hukum yakni sama-sama mencari kebenaran dan keadilan. Siapapun yang melakukan pelanggaran hukum akan mendapat perlakuan yang sama tanpa perbedaan. Setiap orang wajib dianggap tidak bersalah (praduga tak bersalah) sampai kesalahannya dibuktikan dalam sidang pengadilan yang bebas dan jujur di depan umum. Di samping itu, penangkapan atau penahanan yang dilakukan oleh aparat penegak hukum didasarkan pada bukti permulaan yang cukup, tidak semata-mata didasarkan pada keinginan aparat penegak hukum

Pelaksanaan KUHAP oleh aparat penegak hukum sering kali tidak sesuai dengan aturan-aturan yang telah digariskan dalam KUHAP. Untuk mendapatkan keterangan tersangka di tingkat penyidikan, mereka ditangkap saja dulu, kemudian pengakuannya didapatkan dengan cara intimidasi, kekerasan dan penyiksaan.

Akibat proses penyelesaian peristiwa pidana yang demikian banyak kasus hukum mengenai pelanggaran Hak Asasi Manusia (HAM) yang dilakukan oleh aparat penegak hukum. Tersangka, terutama yang miskin menderita akibat perlakuan tidak adil, disiksa, diinterogasi oleh para penegak hukum dan diadili oleh pengadilan yang kejam dan merendahkan martabatnya sebagai manusia, mereka ditahan tanpa proses yang adil, bahkan 
penyelesaian kasus yang ditangani tidak kunjung ada kejelasan. Hal demikian menimbulkan tingkat kepercayaan masyarakat pada dunia peradilan mengalami kemerosotan, ini tercemin dari pola penyelesaian masalah yang dilakukan masyarakat yang cenderung main hakim sendiri.Penyelesaian masalah tersebut menjadi pilihan alternatif di tengah ketidakpercayaan masyarakat terhadap aparatur peradilan. Hal ini sangat dipengaruhi oleh pandangan bahwa proses melalui mekanisme peradilan penuh dengan permainan ketidakadilan serta ketidakpastian yang bertameng kepastian hukum sehingga terjadi konflik dalam kehidupan masyarakat.

Pemberian bantuan hukum oleh advokat/penasehat hukum tentunya sangat penting dalam melindungi dan membela hak-hak pelaku tindak pidana dalam proses mulai dari penyidikan hingga ke persidangan. Hukum Acara Pidana Indonesia memberikan peluang adanya bantuan hukum mulai dari penangkapan atau penahanan tersangka atau terdakwa pada semua tingkat pemeriksaan.

Hal ini diperkuat lagi di dalam Pasal 54 KUHAP yang menyatakan bahwa:

“...Guna kepentingan pembelaan, tersangka atau terdakwa berhak mendapatkan bantuan hukum dari seorang atau lebih penasehat hukum selama dalam waktu dan pada setiap tingkat pemeriksaan, menurut tata cara yang ditentukan dalam undang-undang ini”.

Berdasarkan Pasal 54 KUHAP tersebut, maka dapat disimpulkan bahwa Pasal ini menentukan hak setiap orang untuk mendapatkan bantuan hukum apakah orang itu mampu maupun tidak mampu secara ekonomis. Bantuan hukum ini juga diharapkan dapat mencegah perlakuan tidak adil dan tidak manusiawi atas tersangka atau terdakwa yang tergolong miskin atau yang biasa disebut due process of law atau proses hukum yang adil. ${ }^{2}$

Salah satu hak tersangka adalah untuk mendapatkan bantuan hukum khususnya bagi mereka yang belum paham mengenai hukum bahkan bagi mereka yang berkedudukan sosial menengah ke bawah.Dimana merupakan hal yang harus diperhatikan yaitu hak-hak tersangka khususnya mereka yang kurang mampu dan bagi mereka yang belum paham mengenai hukum.Setiap masyarakat membutuhkan seseorang (figur) yang keteranganketerangannya dapat diandalkan, dapat dipercaya yang tanda tangannya serta segelnya (capnya) memberikan jaminan dan sebagai alat bukti yang kuat.Seseorang (figur) yang dimaksud adalah seorang penasihat hukum/advokat, dimana penasihat hukum atau advokat adalah orang yang memberikan bantuan hukum atau nasihat hukum terhadap klien/pencari keadilan.Dalam kamus umum politik dan hukum mengatakan bahwa Advokat adalah orang

${ }^{2}$ Yudha Pandu, Klien \& Advokat Dalam Praktek, PT. Abadi, Jakarta, 2004, hal. 43 
yang melakukan tugas memberikan bantuan hukum dalam sidang pengadilan, baik perkara perdata maupun pidana; pengacara, ahli hukum. ${ }^{3}$

Profesi Advokat diperlukan dalam hubungannya dengan proses penegakan hukum, termasuk ikut andil dalam menjamin hak seseorang yang perlu diperhatikan dan agar tidak diabaikan atau menegakkan asas hukum praduga tak bersalah (Presumption of Innocence). Dimana tersangka dianggap belum bersalah sebelum adanya putusan hukum yang tetap.

Adanya bantuan hukum dalam hal ini penasihat hukum/advokat mengantisipasi para aparat penegak hukum dalam tahap penyidikan untuk tidak semena-mena terhadap tersangka, apalagi terhadap mereka yang kurang mampu dan mereka yang belum paham mengenai hukum, karena pada realita sekarang untuk mendapatkan bantuan tidak hanya dengan cuma-cuma. Untuk itu diperlukan bantuan hukum khususnya bagi mereka yang kurang mampu dan buta hukum agar supaya apa yang menjadi hak tersangka seperti yang dicantumkan dalam Undang-Undang Nomor 8 Tahun 1981 tentang KUHAP tidak diabaikan atau dikurang oleh penegak hukum dalam setiap pemeriksaan khususnya dalam pemeriksaan di tingkat penyidikan.

Pada dasarnya tugas pokok penasehat hukum (advokat dan pengacara) praktik adalah untuk memberikan legal opinion, serta nasehat hukum dalam rangka menjauhkan klien dari konflik, sedang dilembaga peradilan (beracara dipengadilan) penasehat hukum mengajukan atau membela kliennya. ${ }^{4}$

Dalam Undang-Undang Nomor 18 Tahun 2003 tentang Advokat terdapat hak-hak yang dimiliki oleh advokat yaitu Advokat berhak untuk bebas mengeluarkan pendapat atau pernyataan dalam membela perkara yang menjadi tanggung jawabnya di dalam sidang pengadilan dengan tetap berpegang pada kode etik profesi dan peraturan perundangundangan (Pasal 14).Advokat berhak bebas dalam menjalankan tugas profesinya untuk membela perkara yang menjadi tanggung jawabnya dengan tetap berpegang pada kode etik profesi dan peraturan perundang-undangan (pasal 15). Advokat berhak memperoleh informasi data, dan dokumen lainnya, baik dari instansi Pemerintah maupun pihak lain yang berkaitan dengan kepentingan tersebut yang diperlukan untuk pembelaan kepentingan Kliennya sesuai dengan peraturan perundang-undangan (Pasal 17). Advokat berhak atas kerahasiaan hubungannya dengan Klien, termasuk perlindungan atas berkas dan dokumennya terhadap penyitaan atau pemeriksaan dan perlindungan terhadap penyadapan

\footnotetext{
${ }^{3}$ Telly Sumbu, Merry E. kalalo, Engelien R. Palandeng dan Johny Lumolos,.Kamus Umum Politik dan Hukum, Jala Permata Aksala, Jakarta, 2010.hal. 8

${ }^{4}$ Suhrawardi K Lubis, 2012,, Etika Profesi Hukum, Sinar Garfika, Jakarta, hal. 28
} 
atas komunikasi elektronik Advokat (Pasal 19 ayat 2).Disamping hak-hak tersebut bagi advokat juga memiliki yang namanya hak imunitas dalam menjalankan tugasnya, karena itu undang-undang advokat juga memberikan hak imunitas tersebut pada advokat.

Berkaitan dengan tanggung jawab moral yang dimiliki oleh advokat dan dalam kedudukannya sebagai salah satu pilar atau penyangga dari pelaksanaan sistem peradilan yang adil dan berimbang (fair trial) maka penulis setuju dengan pendapat yang menyatakan bahwa advokat memiliki peran bukan hanya sebagai pembela konstitusi namun juga sebagai pembela hak asasi manusia.Oleh karena itu, maka advokat memiliki fungsi sosial dalam melaksanakan tugasnya.

Salah satu fungsi sosial tersebut adalah memberikan bantuan hukum secara cumacuma khususnya bagi kaum miskin dan buta hukum sebagai bagian dari hak asasi manusia yang dilindungi oleh Undang-undang.Oleh karena itu manusia membutuhkan perlindungan kepentingan-kepntingannya.Dalam pelaksanaan kewajiban memberikan bantuan hukum secara cuma-cuma bagi tersangka khususnya bagi kaum miskin dan buta hukum tersebut memiliki tujuan sebagai berikut: Bagian dari pelaksanaan hak-hak kosntitusional sebagaimana yang diatur dan dijamin oleh UUD 1945 berikut amandemennya. Hak atas bantuan hukum merupakan salah satu dari hak asasi yang harus dilindungi. Dengan mengacu kepada Pasal 27 ayat (1) UUD 1945 termasuk ketentuan Pasal 28 Huruf D ayat (1) dan Pasal 28 Huruf I ayat (1) UUD 1945 yang telah diamandemen tersebut maka hak atas bantuan hukum harus dipandang sebagai suatu lembaga yang wajib dimiliki dan hanya ada di dalam sistem negara hukum. Adanya prinsip hukum yang berdaulat (supremacy of law) dan adanya jaminan terhadap setiap orang yang diduga bersalah untuk mendapatkan proses peradilan yang adil (fair trial) merupakan syarat yang harus dijamin secara absolut dalam negara hukum.

Bagian dari implementasi asas bahwa hukum berlaku bagi semua orang.Adanya keterbatasan pengertian dan pengetahuan hukum bagi individu yang buta hukum untuk memahami ketentuan yang tertulis dalam Undang-undang maka diperlukan peran dan fungsi advokat untuk memberikan penjelasan dan bantuan hukum.Bagian dari upaya standarisasi pelaksanaan peran dan fungsi penegakan hukum dari advokat.

Berdasarkan apa yang dikemukakan ini maka kewajiban pemberian bantuan hukum oleh advokat telah diatur secara tegas dalam Pasal 22 ayat (1) Undang-Undang Nomor 18 Tahun 2003 tentang Advokat. Dalam Pasal 22 ayat (1) tersebut dijelaskan bahwa advokat wajib memberikan bantuan hukum secara cuma-cuma kepada pencari keadilan yang tidak 
mampu.Menurut penulis, bahwa pengaturan yang bersifat penegasan mengenai kewajiban sosial advokat untuk memberikan bantuan hukum secara cuma-cuma kepada kaum miskin merupakan suatu hal yang patut dihargai.Hal ini mengingat bahwa dalam suatu negara berkembang masih banyak terdapat individu atau keluarga yang hidup miskinbahkan di bawah garis kemiskinan.

Bantuan hukum yang diberikan oleh advokat tersebut tentunya berpedoman pada penghargaan terhadap nilai kemanusiaan termasuk didalamnya penghargaan terhadap hak asasi manusia.Mulai dari perihal optimalisasi pemberlakuan sanksi yang tegas terhadap advokat yang tidak melaksanakan kewajiban memberikan bantuan hukum bagi tersangka sampai dengan perihal ketiadaan tolak ukur yang definitif untuk menentukan pihak-pihak mana saja yang dapat dikategorikan sebagai pencari keadilan yang tidak mampu.

Perihal mengenai ketentuan sanksi terhadap advokat yang tidak melaksanakan kewajibannya terdapat dalam Pasal 7 ayat (1) Undang-Undang Nomor 18 Tahun 2003 tentang Advokat, dan Pasal 14 ayat 2 Peraturan Pemerintah Nomor 83 Tahun 2008 telah mengatur beberapa jenis sanksi administratif mulai dari teguran lisan, teguran tertulis, pemberhentian sementara dan pemberhentian tetap.

Apabila dihubungkan dengan ketentuan Pasal 6 huruf (d) Undang-Undang Nomor 18 Tahun 2003 tentang Advokat maka advokat yang tidak melaksanakan kewajiban pemberian bantuan hukum dapat dikategorikan telah melakukan perbuatan yang bertentang dengan kewajiban profesi sebagaimana yang dijelaskan dalam Pasal 22 ayat (1) UndangUndang Nomor 18 Tahun 2003. Oleh karena itu, maka sanksi-sanksi sebagaimana yang dijelaskan dalam Pasal 7 ayat (1) Undang-Undang Nomor 18 Tahun 2003 dan Pasal 14 ayat 2 Peraturan Pemerintah Nomor 83 Tahun 2008 dapat diberlakukan kepada advokat yang tidak melaksanakan kewajiban pemberian bantuan hukum sebagai profesi yang dijalankannya.

Selanjutnya, pelaksanaan kewajiban pemberian bantuan hukum oleh advokat tidak dapat dilepaskan dari peranan organisasi advokat itu sendiri.Hal ini dikarenakan alasan bahwa organisasi advokat berfungsi untuk melakukan pengawasan.Sebagaimana yang dijelaskan dalam Pasal 12 ayat (1) Undang-Undang Nomor 18 Tahun 2003 tentang Advokat yang menerangkan bahwa pengawasan terhadap advokat dilakukan oleh Organisasi advokat. Sedangkan dalam Pasal 12 ayat (1) Undang-Undang Nomor 18 Tahun 2003 tentang Advokat yang menerangkan bahwa pengawasan tersebut dilakukan dengan 
tujuan agar advokat selalu menjunjung tinggi kode etik profesi dan peraturan perundangundangan dalam melaksanakan tugasnya.

Sesuai dengan pengertian dari bantuan hukum menurut Pasal 1 ayat (1) Undangundang Nomor 16 tahun 2011 tentang Bantuan Hukum, yaitu bantuan hukum adalah jasa hukum yang diberikan pemberi bantuan hukum secara cuma-cuma kepada penerima bantuan hukum. Defenisi yang sama juga diberikan oleh Undang-undang Nomor 18 tahun 2003 tentang Advokat. Maka dengan melihat defenisi yang diberikan kedua undangundang tersebut, bahwa bantuan hukum mengandung unsur jasa hukum yang diberikan secara cuma-cuma.

\section{B. Perumusan Masalah}

Adapun pertanyaan-pertanyaan penelitian yang memfokuskan permasalahan di atas adalah:

1. Bagaimanakah Peran Penasehat Hukum dalam Membantu Tersangka pada Penyidikan Guna Terciptanya Proses Hukum yang Adil?;

2. Bagaimanakah konsepsi pembaharuan hukum acara pidana tentang peran Penasihat Hukum dalam penyidikan, sehingga mampu menciptakan penyidikan yang bebas dari kekerasan dan penyiksaan demi tercapainya hakikat penegakan hukum yakni proses hukum yang adil?.

\section{Metode Penelitian}

\section{Tipe Penelitian}

Mengacu pada perumusan masalah dan tujuan penelitian tersebut di atas, maka penelitian ini dilakukan dengan menggunakan penelitian yuridis normatif. Penelitian hukum normatif mencakup penelitian terhadap asas-asas hukum, sistematika hukum, sinkronisasi hukum, dan sejarah hukum. Penelitian normatif diambil sebagai pendekatan utama dalam penelitian ini karena yang menjadi perhatian utama adalah ketentuan KUHAP, yang mengatur mengenai peran Penasihat Hukum dalam proses penyidikan.

2. Pendekatan Penelitian

Pendekatan yang digunakan dalam penelitian ini, sesuai dengan rumusan masalah sebagai objek penelitian yang akan dibahas dan dijawab. Maka pendekatan yang digunakan pendekatan konseptual, pendekatan peraturan perundang-undangan dan pendekatan sejarah. Pendekatan Konsep dilakukan dengan meneliti asas-asas hukum pidana, teori-teori 
kebijakan kriminal, kebijakan hukum pidana dan teori pemidanaan. Pendekatan perundang-undangan dilakukan dengan meneliti konsep perundang-undangan yang relevan dengan penelitian ini, baik berbentuk hukum positif maupun yang masih berbentuk rancangan. Sementara pendekatan sejarah dikakukan dengan meneliti latar belakang lahirnya KUHAP dan pengaturan mengenai peran Penasihat Hukum menurut hukum acara pidana nasional.

Setelah bahan-bahan hukum terkumpul, maka dilakukan analisis terhadap pengertian-pengertian hukum dan norma-norma hukum, dengan cara melihat isi dari berbagai macam peraturan perundang-undangan yang berhubungan dengan masalah proses peradilan pidana.

Pengkajian terhadap isi bahan hukum dengan melakukan interpretasi, menilai dan melakukan evaluasi terhadap semua kebijakan hukum pidana yang berhubungan dengan masalah pemidanaan, hukum acara pidana, sistem peradilan pidana baik berupa hukum positif maupun yang masih berbentuk konsep.

\section{Peran penasehat hukum dalam membantu tersangka pada penyidikan guna terciptanya proses hukum yang berbeda}

1.Peran Penasihat Hukum Dalam Membantu Tersangka pada Penyidikan.

Sebelum melakukan pengkajian mengenai peran Penasihat Hukum dalam menciptakan penyidikan yang bebas dari intimidasi, kekerasan dan penyiksaan, perlu ditinjau terlebih dahulu peran Penasihat Hukum dalam sistem peradilan pidana, menurut perundang-undangan Indonesia.

Dalam perspektif perundang-undangan Indonesia, peran Penasihat Hukum diatur di dalam KUHAP dan Undang-Undang Advokat. Di dalam Pasal 1 angka 13 KUHAP, dijelaskan bahwa yang dimaksud dengan Penasihat Hukum adalah seorang yang memenuhi syarat yang ditentukan oleh atau berdasarkan undang-undang untuk memberi bantuan hukum.

Selanjutnya, peran Penasihat Hukum diatur secara khusus di dalam Bab VII yang meliputi Pasal 69 sampai dengan Pasal 74 KUHAP. Di dalam Pasal 69, digariskan bahwa "Penasihat hukum berhak menghubungi tersangka sejak saat ditangkap atau ditahan pada semua tingkat pemeriksaan menurut tatacara yang ditentukan dalam undang-undang ini”.

Pasal 70 dan Pasal 71 KUHAP mengatur tentang tatacara penggunaan hak Penasihat Hukum, yang selengkapnya menggariskan bahwa: 
Pasal 70:

(1) Penasihat hukum sebagaimana dimaksud dalam Pasal 69 berhak menghubungi dan berbicara dengan tersangka pada setiap tingkat pemeriksaan dan setiap waktu untuk kepentingan pembelaan perkaranya.

(2) Jika terdapat bukti bahwa penasihat hukum tersebut menya-lahgunakan haknya dalam pembicaraan dengan tersangka maka sesuai dengan tingkat pemeriksaan, penyidik, penuntut umum atau petugas lembaga pemasyarakatan memberi peringatan kepada penasihat hukum.

(3) Apabila peringatan tersebut tidak diindahkan, maka hubungan tersebut diawasi oleh pejabat yang tersebut pada ayat (2).

Pasal 71:

(1) Penasihat hukum, sesuai dengan tingkat pemeriksaan, dalam berhubungan dengan tersangka diawasi oleh penyidik, penuntut umum atau petugas lembaga pemasyarakatan tanpa mendengar isi pembicaraan.

(2) Dalam hal kejahatan terhadap keamanan negara, pejabat tersebut pada ayat (1) dapat mendengar isi pembicaraan.

Kemudian, Pasal 72 KUHAP mengatur tentang hak tersangka mendapatkan turunan Berita Acara Pemeriksaan (BAP) melalui Penasihat Hukum, dimana dinyatakan bahwa "Atas permintaan tersangka atau penasihat hukumnya pejabat yang bersangkutan memberikan turunan berita acara pemeriksaan untuk kepentingan pernbelaannya".

Di dalam Penjelasan KUHAP, diuraikan bahwa yang dimaksud dengan "untuk kepentingan pembelaannya" di dalam Pasal 72 ialah bahwa mereka wajib menyimpan isi berita acara tersebut untuk diri sendiri. Yang dimaksud dengan "turunan" ialah dapat berupa foto copy. Yang dimaksud dengan "pemeriksaan" dalam pasal ini ialah pemeriksaan dalam tingkat penyidikan, hanya untuk pemeriksaan tersangka. Dalam tingkat penuntutan ialah semua berkas perkara termasuk surat dakwaan. Pemeriksaan di tingkat pengadilan adalah seluruh berkas perkara termasuk putusan hakim.

Seterusnya, Pasal 73 KUHAP mengatur tentang hak Penasihat Hukum menerima surat dari tersangka, yang pada pokoknya menggariskan bahwa Penasihat hukum berhak mengirim dan menerima surat dan tersangka setiap kali dikehendaki olehnya.

Sementara di dalam Pasal 74 KUHAP, diatur tentang pengurangan hak akibat penyalahgunaan hak oleh Penasihat Hukum. Ketentuan dimaksud selengkapnya menyatakan sebagai berikut: 


\section{Pasal 74:}

Pengurangan kebebasan hubungan antara penasihat hukum dan tersangka sebagaimana tersebut pada Pasal 70 ayat (2), ayat (3), ayat (4) dan Pasal 71 dilarang, setelah perkara dilimpahkan oleh penuntut umum kepada pengadilan negeri untuk disidangkan, yang tembusan suratnya disampaikan kepada tersangka atau penasihat hukumnya serta pihak lain dalam proses.

Kemudian dari pada itu, peran Penasihat Hukum diatur secara khusus dalam Undang-Undang Advokat. Undang-Undang yang disahkan pada tanggal 5 April 2003, ditempatkan pada Lembaran Negara Republik Indonesia Tahun 2003 Nomor 49 dan ditandatangani oleh Presiden Megawati tersebut, lahir berdasarkan pertimbangan antara lain bahwa dalam usaha mewujudkan prinsip-prinsip negara hukum dalam kehidupan bermasyarakat dan bernegara, peran dan fungsi Advokat sebagai profesi yang bebas, mandiri dan bertanggung jawab merupakan hal yang penting, di samping lembaga peradilan dan instansi penegak hukum seperti kepolisian dan kejaksaan.

Melalui jasa hukum yang diberikan, Advokat menjalankan tugas profesinya demi tegaknya keadilan berdasarkan hukum untuk kepentingan masyarakat pencari keadilan, termasuk usaha memberdayakan masyarakat dalam menyadari hak-hak fundamental mereka di depan hukum.

Advokat sebagai salah satu unsur sistem peradilan merupakan salah satu pilar dalam menegakkan supremasi hukum dan hak asasi manusia. Selain dalam proses peradilan, peran Advokat juga terlihat di jalur profesi di luar pengadilan. Kebutuhan jasa hukum Advokat di luar proses peradilan pada saat sekarang semakin meningkat, sejalan dengan semakin berkembangnya kebutuhan hukum masyarakat terutama dalam memasuki kehidupan yang semakin terbuka dalam pergaulan antarbangsa. Melalui pemberian jasa konsultasi, negosiasi maupun dalam pembuatan kontrak-kontrak dagang, profesi Advokat ikut memberi sumbangan berarti bagi pemberdayaan masyarakat serta pembaharuan hukum nasional khususnya di bidang ekonomi dan perdagangan, termasuk dalam penyelesaian sengketa di luar pengadilan.

Kendati keberadaan dan fungsi Advokat sudah berkembang sebagaimana dikemukakan, peraturan perundang-undangan yang mengatur institusi Advokat sampai saat dibentuknya Undang-Undang ini masih berdasarkan pada peraturan perundang-undangan peninggalan zaman kolonial, seperti ditemukan dalam Reglement op de Rechterlijke Organisatie en het Beleid der Justitie in Indonesie (Stb. $1847: 23$ jo. Stb.1848 : 57), Pasal 
185 sampai Pasal 192 dengan segala perubahan dan penambahannya kemudian, Bepalingen betreffende het kostuum der Rechterlijke Ambtenaren dat der Advokaten, procureurs en Deuwaarders (Stb. 1848 : 8), Bevoegdheid departement hoofd in burgelijke zaken van land (Stb. 1910 : 446 jo. Stb. 1922: 523), dan Vertegenwoordiging van de land in rechten (K.B.S 1922 : 522).

Untuk menggantikan peraturan perundang-undangan yang diskriminatif dan yang sudah tidak sesuai lagi dengan sistem ketatanegaraan yang berlaku, serta sekaligus untuk memberi landasan yang kokoh pelaksanaan tugas pengabdian Advokat dalam kehidupan masyarakat, maka dibentuk Undang-Undang ini sebagaimana diamanatkan pula dalam Pasal 38 Undang-Undang Nomor 14 Tahun 1970 tentang Ketentuan-ketentuan Pokok Kekuasaan Kehakiman, sebagaimana diubah dengan Undang-Undang Nomor 48 Tahun 1999.

Beberapa terminologi atau istilah yang patut difahami dalam Undang-Undang Advokat, adalah pengertian tentang Advokat, jasa hukum dan bantuan hukum. Di dalam Pasal 1 angka 1, dijelaskan bahwa "Advokat adalah orang yang berprofesi memberi jasa hukum, baik di dalam maupun di luar pengadilan yang memenuhi persyaratan berdasarkan ketentuan Undang-Undang ini”. Tentang jasa hukum, diuraikan dalam Pasal 1 angka 2, bahwa "Jasa Hukum adalah jasa yang diberikan Advokat berupa memberikan konsultasi hukum, bantuan hukum, menjalankan kuasa, mewakili, mendampingi, membela, dan melakukan tindakan hukum lain untuk kepentingan hukum klien”. Sedangkan pengertian mengenai bantuan hukum, dijelaskan dalam Pasal 1 angka 9 bahwa "Bantuan Hukum adalah jasa hukum yang diberikan oleh Advokat secara cuma-cuma kepada Klien yang tidak mampu".

Di samping itu, terdapat beberapa ketentuan penting di dalam Undang-Undang Advokat, antara lain persyaratan untuk dapat diangkat menjadi Advokat, peran Advokat, dan hak serta kewajiban seorang Advokat atau Penasihat Hukum.

Tentang persyaratan untuk dapat diangkat menjadi Advokat, diatur di dalam Pasal 3 Undang-Undang Advokat, yang pada prinsipnya menjelaskan bahwa untuk dapat diangkat menjadi Advokat, harus memenuhi persyaratan sebagai berikut :

a. warga negara Republik Indonesia;

b. bertempat tinggal di Indonesia;

c. tidak berstatus sebagai pegawai negeri atau pejabat negara;

d. berusia sekurang-kurangnya 25 (dua puluh lima) tahun; 
e. berijazah sarjana yang berlatar belakang pendidikan tinggi hukum (lulusan fakultas hukum, fakultas syariah, perguruan tinggi hukum militer, dan perguruan tinggi ilmu kepolisian)

f. lulus ujian yang diadakan oleh Organisasi Advokat;

g. magang sekurang-kurangnya 2 (dua) tahun terus menerus pada kantor Advokat;

h. tidak pernah dipidana karena melakukan tindak pidana kejahatan yang diancam dengan pidana penjara 5 (lima) tahun atau lebih;

i. berperilaku baik, jujur, bertanggung jawab, adil, dan mempunyai integritas yang tinggi.

Mengenai peran Advokat, digariskan dalam Bagian Ketiga tentang status, yang meliputi 1 (satu) Pasal yakni Pasal 5, yang pada pokoknya menggariskan bahwa Advokat berstatus sebagai penegak hukum, bebas dan mandiri yang dijamin oleh hukum dan peraturan perundang-undangan. Wilayah kerja Advokat meliputi seluruh wilayah negara Republik Indonesia.

Di dalam penjelasan Undang-Undang advokat, diuraikan bahwa yang dimaksud dengan "Advokat berstatus sebagai penegak hukum" adalah Advokat sebagai salah satu perangkat dalam proses peradilan yang mempunyai peran setara dengan penegak hukum lainnya dalam menegakkan hukum dan keadilan.

Selanjutnya tentang hak dan kewajiban Advokat, diatur di dalam Bab IV yang meliputi Pasal 14 sampai dengan Pasal 20 Undang-Undang Advokat. Dari ketentuan pasalpasal dimaksud, yang menjadi hak Advokat adalah sebagai berikut:

1. Bebas mengeluarkan pendapat atau pernyataan dalam membela perkara yang menjadi tanggung jawabnya di dalam sidang pengadilan dengan tetap berpegang pada kode etik profesi dan peraturan perundang-undangan;

2. Tidak dapat dituntut baik secara perdata maupun pidana dalam menjalankan tugas profesinya dengan iktikad baik untuk kepentingan pembelaan Klien dalam sidang pengadilan;

3. Memperoleh informasi, data, dan dokumen lainnya, baik dari instansi Pemerintah maupun pihak lain yang berkaitan dengan kepentingan tersebut yang diperlukan untuk pembelaan kepentingan Kliennya sesuai dengan peraturan perundang-undangan; 
4. Atas kerahasiaan hubungannya dengan Klien, termasuk perlin-dungan atas berkas dan dokumennya terhadap penyitaan atau pemeriksaan dan perlindungan terhadap penyadapan atas komunikasi elektronik Advokat;

5. Tidak diidentikkan dengan Kliennya dalam membela perkara Klien oleh pihak yang berwenang dan/atau masyarakat.

Sedangkan kewajiban Advokat menurut ketentuan Undang-Undang Advokat, meliputi hal-hal sebagai berikut:

1. Dalam menjalankan tugas profesinya dilarang membedakan perlakuan terhadap Klien berdasarkan jenis kelamin, agama, politik, keturunan, ras, atau latar belakang sosial dan budaya;

2. Wajib merahasiakan segala sesuatu yang diketahui atau diperoleh dari Kliennya karena hubungan profesinya, kecuali ditentukan lain oleh Undang-undang;

3. Dilarang memegang jabatan lain yang bertentangan dengan kepentingan tugas dan martabat profesinya;

4. Tidak melaksanakan tugas profesi Advokat selama memangku jabatan tersebut, selama menjadi pejabat negara.

Berdasarkan ketentuan perundang-undangan Indonesia di atas, disimpulkan bahwa Penasihat Hukum atau sering disebut Advokat, Pengacara atau Kuasa Hukum, merupakan penegak yang bebas dan mandiri, dan keberadaannya dijamin oleh hukum dan peraturan perundang-undangan. Penasihat Hukum adalah salah satu perangkat dalam proses peradilan yang mempunyai peran setara dengan penegak hukum lainnya dalam menegakkan hukum dan keadilan.

Dengan demikian, Penasihat Hukum memiliki peran yang penting dan strategis dalam sistem peradilan pidana Indonesia, yang menjalankan fungsi check and balances terhadap fungsi penegak hukum lainnya, sejak dari tahapan penyidikan sampai dengan pelaksanaan putusan pidana.

Di pundak Penasihat Hukumlah, diletakkan tanggungjawab yang demikian mulia untuk memastikan bahwa seluruh penanganan perkara pidana, telah dilaksanakan sesuai kaidah proses hukum yang adil (due process of law), dimana di dalamnya hak-hak tersangka, terdakwa dan terpidana, dilindungi, dihormati dan dipenuhi, dan dianggap sebagai bagian dari hak-hak warga negara (civil rights) dan karena itu bagian dari hak asasi manusia. 
Terkait dengan pemenuhan hak-hak tersangka, telah dikemukakan sebelumnya bahwa KUHAP mengatur secara khusus hak-hak seorang tersangka, yang harus dipenuhi dan dihormati oleh penyidik, selama yang bersangkutan menjalani tahapan penyidikan.

Hak-hak tersangka tersebut, termaktub di dalam Pasal 50 sampai dengan Pasal 68 KUHAP, yang pada pokoknya mengatur mengenai 19 (sembilan belas) hak tersangka, yang dijamin oleh KUHAP untuk dilaksanakan secara penuh tanpa dapat dikurangi sedikitpun.

Hak-hak dimaksud meliputi hak untuk segera mendapat pemeriksaan oleh penyidik dan selanjutnya segera diajukan kepada Penuntut Umum, dimajukan ke pengadilan, dan segera diadili oleh pengadilan, hak untuk diberitahukan dengan tentang apa yang disangkakan dan didakwakan kepadanya pada waktu pemeriksaan dimulai, hak memberikan keterangan secara bebas kepada penyidik atau hakim, hak untuk setiap waktu mendapat bantuan juru bahasa, hak mendapatkan bantuan hukum dari seseorang atau lebih penasihat hukum selama dalam waktu dan pada setiap tingkat pemeriksaan, hak untuk mendapat dan memilih sendiri penasihat hukum, hak untuk mendapat penasihat hukum secara cuma-cuma, bagi tersangka atau terdakwa yang diancam pidana mati atau pidana lima belas tahun ataupun lebih, atau yang tidak mampu yang diancam dengan lima tahun atau lebih yang tidak mempunyai penasihat hukum sendiri, hak menghubungi penasihat hukumnya, hak menghubungi dan menerima kunjungan dokter pribadinya untuk kepentingan kesehatan, bagi yang ditahan, hak diberitahukan tentang penahanan atas dirinya, kepada keluarganya atau orang lain yang serumah dengannya, ataupun orang lain yang bantuannya dibutuhkan oleh tersangka untuk mendapatkan bantuan hukum atau jaminan bagi penangguhannya, apabila ia ditahan, hak menghubungi dan menerima kunjungan dari pihak keluarga atau lainnya guna mendapatkan bantuan hukum, hak secara langsung atau dengan perantaraan penasihat hukumnya menghubungi dan menerima kunjungan sanak keluarganya dalam hal yang tidak ada hubungannya dengan perkara tersangka atau terdakwa untuk kepentingan pekerjaan atau untuk kepentingan kekeluargaan, hak mengirim dan menerima surat kepada atau dari penasihat hukumnya, menerima surat dari sanak keluarganya setiap kali yang diperlukan olehnya, hak untuk menghubungi dan menerima kunjungan dari rohaniawan hak untuk diadili di sidang pengadilan yang terbuka untuk umum, hak untuk mengusahakan dan mengajukan saksi atau seseorang yang memiliki keahlian khusus guna memberikan keterangan yang menguntungkan bagi dirinya, berhak untuk tidak dibebani kewajiban pembuktian, hak 
untuk minta banding terhadap putusan pengadilan tingkat pertama kecuali terhadap putusan bebas, lepas dari segala tuntutan hukum yang menyangkut masalah kurang tepatnya penerapan hukum dan putusan pengadilan dalam acara cepat, dan hak menuntut ganti kerugian dan rehabilitasi.

Perumusan mengenai hak-hak tersangka di dalam KUHAP sebagaimana diuraikan di atas, secara jelas dapat dipandang sebagai perwujudan yang nyata dari tujuan penegakan hukum, yang ingin dicapai oleh Indonesia sebagai negara hukum (rechstaat), yakni terpenuhinya asas keadilan dan kebenaran, dimana di dalam memperoleh keadilan dan kebenaran tersebut hak-hak pelanggar hukum, sebagai bagian dari hak asasi manusia, harus dihormati, dipenuhi dan dilindungi.

Dengan demikian, dapat dirasakan betapa penting dan strategisnya kehadiran dan eksistensi KUHAP dalam penegakan hukum. Terkait dengan hal itu, Komisi Hukum Nasional Republik Indonesia (KHN RI), mengung-kapkan bahwa sejak awal keberadaannya, hukum pidana dan hukum acara pidana, diperuntukakan melindungi masyarakat dari kesewenang-wenangan penguasa. Dalam hal ini J.E. Sahetapy, meminjam konsep Jerome H. Skolnick mengatakan bahwa "criminal procedure is intended to control authorities, not criminals".

Pendapat senada disampaikan oleh Mardjono Reksodiputro, yang mengatakan bahwa:

Fungsi dari Undang-Undang Acara Pidana adalah untuk membatasi kekuasaan negara dalam bertindak terhadap warga masyarakat yang terlibat dalam proses peradilan pidana. Namun di sisi lain, hukum acara pidana juga memberikan kewenangankewenangan tertentu kepada negara melalui penegak hukum untuk melakukan tindakantindakan yang dapat melanggar hak asasi warganya.

Terhadap kewenangan penegak hukum yang dapat menimbulkan pelanggaran hak asasi manusia tersebut, Loebby Loqman seperti dikuti KHN RI, berpendapat bahwa hukum acara pidana seharusnya mampu menjaga batas antara kewenangan upaya paksa aparat penegak hukum (penangkapan, pena-hanan, penyitaan, penggeledahan) dengan perlindungan hak tersangka, sehingga dapat mencerminkan hukum acara pidana dalam lingkup suatu negara hukum. Oleh karenanya dalam hukum acara pidana, harus ada suatu batasan yang tegas, terutama berkaitan dengan pembatasan hak asasi tersangka, sebab dilakukannya upaya paksa, maka dengan sendirinya telah terjadi pelanggaran hak asasi 
seseorang. Penggunaan upaya paksa di lain pihak tidak lain dilakukan untuk mencari bukti bahwa seseorang telah melakukan suatu tindak pidana. ${ }^{5}$

Apabila dalam tataran normatif, KUHAP sudah merumuskan perlindungan terhadap hak tersangka, namun pada praktik atau pada tataran implementatif, perumusan KUHAP tentang perlindungan hak tersebut, belum sepenuhnya dapat dilaksanakan secara efektif.

Mencermati seluruh hak tersangka sebagaimana diatur di dalam, Pasal 50 sampai dengan Pasal 68 KUHAP, terdapat 1 (satu) hak yang bersifat prinsipil dan dapat mempengaruhi pemenuhan hak-hak lainnya. Hak tersangka dimaksud adalah hak untuk memberikan keterangan secara bebas kepada penyidik atau hakim, sebagaimana diatur di dalam Pasal 52 KUHAP.

Disebut sebagai hak yang bersifat prinsipil, karena ketentuan Pasal 52 KUHAP tersebut sangat rawan untuk diabaikan dan atau disalah-gunakan, sedemikian sehinga penyidikan diwarnai dengan intimidasi, kekerasan dan atau penyiksaan oleh oknum penyidik.

Terkait dengan hal itu, Komisi Hukum Nasional Republik Indonesia (KHN RI), menjelaskan bahwa:

Meskipun KUHAP memberikan perlindungan pada hak tersangka/terdakwa/terpidana tetapi terdapat ketentuan pasal KUHAP yang memberikan kewenangan yang besar kepada Kepolisian dam Kejaksaan dalam proses hukum pidana yang berpotensi menimbulkan arogansi kekuasaan (the arrogance of power) yang selalu berbarengan dengan penyalah-gunaan kekuasaan (abuse of power). Tentang arogansi kekuasaan dan penyalah-gunaan kekuasaan, KHN RI menjelaskan lebih lanjut bahwa dapat dipastikan titik rawan penyimpangan terletak dalam penyidikan dan penuntutan yang saling berkaitan dan merupakan sub-sistem peradilan. Penyidikan yang dilakukan dengan kekerasan (violence) atau penyiksaan (torture) oleh penyidik terhadap tersangka, merupakan suatu kegagalan dari sub-seistem lainnya dan mempengaruhi sistem peradilan pidana secara keseluruhan.

Pasal 52 KUHAP menggariskan bahwa "Dalam pemeriksaan tersangka atau terdakwa berhak memberikan keterangan secara bebas kepada penyidik atau hakim". Adapun yang dimaksud dengan "berhak memberikan keterangan secara bebas", dijelaskan dalam Penjelasan KUHAP, bahwa "Supaya pemeriksaan dapat mencapai hasil yang tidak

\footnotetext{
${ }^{5}$ Ibid., hal. 3 .
} 
menyimpang daripada yang sebenarnya maka tersangka atau terdakwa harus dijauhkan dari rasa takut. Oleh karena itu wajib dicegah adanya paksaan atau tekanan terhadap tersangka atau terdakwa".

Berdasarkan perumusan Pasal 52 KUHAP di atas, disimpulkan bahwa KUHAP telah secara tegas mengamanatkan agar proses pidana terhadap seorang tersangka, haruslah benar-benar bersih dari tindakan intimidasi, kekerasan dan penyiksaan.

Untuk menjamin pelaksanaan penyidikan yang bebas dari tindakan intimidasi, kekerasan dan penyiksaan, KUHAP mengatur antara lain mengenai peran dan peran Penasehat Hukum. Peran penting yang diemban oleh Penasihat Hukum, secara eksplisit dirumuskan dalam Pasal 54 KUHAP dan Asas-asas KUHAP. Di dalam Pasal 54 KUHAP, ditegaskan bahwa "Guna kepentingan pembelaan, tersangka atau terdakwa berhak mendapat bantuan hukum dari seseorang atau lebih penasihat hukum selama dalam waktu dan pada setiap tingkat pemeriksaan".

Selanjutnya, di dalam 10 (sepuluh) asas yang melandasi lahirnya dan menjiwai perumusan pasal-pasal di dalam KUHAP tersebut, 2 (dua) diantaranya merumuskan tentang Penasihat Hukum. Kedua asas dimaksud adalah asas ke-enam dan ke-tujuh, yang mengamanatkan bahwa "Setiap orang yang tersangkut perkara wajib diberi kesempatan memperoleh bantuan hukum yang semata-mata diberikan untuk melaksanakan kepentingan pembelaan dirinya", dan "Kepada seorang tersangka sejak saat dilakukan penangkapan dan atau penahanan selain wajib diberitahu dakwaan dan dasar hukum apa yang didakwakan kepadanya, juga wajib diberitahu haknya itu termasuk hak untuk menghubungi dan minta bantuan penasehat hukum".

Beranjak dari perumusan Pasal 54 dan asas-asas KUHAP di atas, disimpulkan bahwa KUHAP menganut prinsip dasar yang jelas dan tegas, bahwa tersangka berhak menghubungi dan minta bantuan penasihat hukum, sejak saat dilakukan penangkapan.

Dengan demikian, dapat ditarik pengertian bahwa pada saat dilakukan penangkapan, seorang yang disangka melakukan suatu kejahatan, wajib diberi kesempatan untuk menghubungi dan minta bantuan Penasihat Hukum untuk mendampinginya. Apabila tersangka menyatakan bahwa ia akan didampingi Penasihat Hukum, dalam batas waktu tertentu penyidik harus menunggu kehadiran Penasihat Hukum dimaksud.

Asas ini merupakan asas yang sangat penting, bagi terpenuhinya hak tersangka untuk terhindar dari tindakan intimidasi, kekerasan dan penyiksaan. Masa antara penangkapan sampai dengan tibanya tersangka di kantor Kepolisian, dan dimulainya 
proses pemeriksaan, merupakan masa-masa paling "gelap", dimana pada saat itu yang ada hanyalah tersangka dan penyidik yang melakukan penangkapan.

Oleh karenanya, masa penangkapan menjadi masa-masa yang paling rawan akan terjadinya tindakan intimidasi, kekerasan dan penyiksaan oleh oknum penyidik, untuk mendapatkan pengakuan tersangka. Sejumlah kasus penganiayaan dan penyiksaan terhadap orang yang disangka melakukan kejahatan, antara lain kejahatan pencurian dan pencurian dengan kekerasan yang selama ini kerap muncul di media, pada umumnya terjadi pada masa penangkapan sampai dengan tibanya tersangka itu ke kantor Polisi.

Dengan pengaturan Pasal 54 dan asas KUHAP, yang mewajibkan pemberian kesempatan kepada tersangka untuk menghubungi dan minta bantuan penasihat hukum untuk mendampinginya, seyogyanya saat setelah penangkapan dan atau hendak di bawa ke kantor Polisi, seyogyanya tersangka telah didampingi oleh Penasihat Hukum, sedemikian sehingga masa-masa penangkapan, menjadi terang benderang atau transparan, yang dapat menutup atau setidaknya meminimalisir kemungkinan terjadinya kekerasan dan penyiksaan, terhadap seorang tersangka oleh penyidik.

Pertanyaan mendasarnya adalah, manakala KUHAP sudah mengatur sedemikian rupa tentang perlunya kehadiran Penasehat Hukum sejak penangkapan, untuk menciptakan proses hukum yang adil (due process of law) dalam penyidikan, mengapa sampai hari ini ketentuan tersebut tidak berlaku, sehingga masih kerap terjadi kekerasan dan penyiksaan oleh oknum penyidik terhadap seorang tersangka?.

Untuk menjawab pertanyaan tersebut, pendapat Mardjono Reksodiputro dapat dijadikan alat analisis. Ahli hukum pidana itu mengatakan bahwa di dalam hukum ada adagium yang mengatakan bahwa dimana ada hak, maka selalu harus ada kemungkinan untuk menuntut dan memperolehnya apabila dilanggar (ubi jus ibi remedium). Kelanjutan logis dari asas ini adalah penafsiran bahwa, hanya apabila ada proses hukum untuk menuntutnya, dapat dikatakan adanya hak bersangkutan (ubi remedium ibi jus).

Berangkat dari pendapat Mardjono Reksodiputro di atas, dilakukan penelitian apakah ada ketentuan di dalam KUHAP yang mengatur tentang proses hukum yang disediakan bagi tersangka untuk menuntut haknya didampingi Penasehat Hukum, saat dilakukan penangkapan atau pada saat tersangka hendak di bawa oleh penyidik.

Setelah mencermati pasal-pasal di dalam KUHAP, ternyata tidak ditemukan ketentuan yang dimaksud. Artinya, KUHAP memang mewajibkan penyidik untuk memberikan kesempatan kepada tersangka, menghubungi dan minta bantuan penasihat 
hukum untuk mendampinginya sejak saat ia ditangkap, namun KUHAP sama sekali tidak mengatur tentang akibat hukum bagi penyidik dan penyidikan perkara bersangkutan, apabila penyidik tidak menunaikan kewajibannya itu.

Ketiadaan konsekuensi hukum atas tidak diberikannya hak tersangka tersebut, tentu saja akan menyebabkan tidak adanya jaminan bahwa hak-hak tersangka terutama hak untuk mendapatkan pendampingan saat penangkapan, akan benar-benar dipenuhi secara nyata.

Ketiadaan jaminan hukum terhadap ditunaikannya kewajiban penyidik untuk memberikan kesempatan kepada tersangka, menghubungi dan minta bantuan penasihat hukum untuk mendampinginya, maka menjadi suatu hal yang biasa dalam praktik penangan perkara selama ini, dimana orang yang disangka melakukan tindak pidana, tidak didampingi siapapun saat ditangkap atau di "gelandang" ke kantor Polisi.

Berdasarkan analisis di atas, disimpulkan bahwa dalam perspektif perundangundangan Indonesia, peran Penasihat Hukum dalam penyidikan diatur di dalam UndangUndang Advokat dan KUHAP. Di dalam Undang-Undang Advokat ditegaskan bahwa Penasihat Hukum merupakan penegak hukum yang bebas dan mandiri, dan keberadaannya dijamin oleh hukum dan peraturan perundang-undangan.Penasihat Hukum adalah salah satu perangkat dalam proses peradilan yang mempunyai peran setara dengan penegak hukum lainnya dalam menegakkan hukum dan keadilan. Terkait dengan penyidikan yang bebas dari intimidasi, kekerasan dan penyiksaan, KUHAP telah menempatkan Penegak Hukum pada posisi yang strategis. KUHAP secara tegas telah mengamanatkan bahwa penyidik wajib memberikan kesempatan kepada tersangka, menghubungi dan minta bantuan penasihat hukum untuk mendampinginya, sejak saat orang yang diduga melakukan kejahatan itu ditangkap. Dengan kehadiran Penasihat Hukum saat setelah penangkapan atau sebelum tersangka dibawa ke kantor Polisi, penyidik menjadi "terhalang" untuk melakukan intimidasi, kekerasan dan penyiksaan terhadap tersangka. Namun demikian, ketentuan KUHAP tersebut dalam praktiknya hampir tidak pernah dilaksanakan. Hal itu terjadi karena adanya fenomena hukum berupa kekosongan norma (vacuum of norm) di dalam KUHAP, yang mengatur mengenai sanksi atau akibat hukum bagi penyidik dan penyidikan perkara bersangkutan, yang mengabaikan kewajiban memberikan kesempatan kepada tersangka, menghubungi dan minta bantuan penasihat hukum untuk mendampinginya. Ketiadaan pengaturan tentang hal tersebut sangat berpotensi menimbulkan penyalah-gunaan kekuasaan oleh penyidik, dengan melakukan 
intimidasi, kekerasan dan penyiksaan demi memperoleh keterangan "yang diinginkan" dari seorang tersangka. Tindakan penyidik yang demikian pada gilirannya akan sangat menciderai hakekat atau tujuan mendasar dari penegakan hukum yakni terciptanya proses hukum yang adil (due process of law).

2. Konsepsi Pembaharuan Hukum Acara Pidana Tentang Peran Penasihat Hukum Dalam Penyidikan, Sehingga Mampu Menciptakan Penyidikan Yang Bebas Dari Kekerasan Dan Penyiksaan Demi Tercapainya Hakikat Penegakan Hukum Yakni Proses Hukum Yang Adil.

Pada bagian terdahulu, telah diuraikan bagaimana hubungan antara hak untuk didamping penasehat hukum, dengan keksongan norma di dalam KUHAP yang mengatur tentang akibat hukum dari tidak didampinginya seorang tersangka pada saat penangkapan. Dampak dari pengabaian terhadap norma kewajiban kehadiran Penasihat Hukum pada saat penangkapan tersebut, jelas sangat luas yakni tidak tercapainya proses hukum yang adil, sebagai kriteria utama keberhasilan pencapaian hakikat penegakan hukum.

Dengan demikian, dalam perumusan mengenai kewajiban kehadiran Penasihat Hukum untuk mendampingi tersangka sejak penangkapan, telah terjadi ketidak seimbangan antara perumusan kewajiban penyidik dengan hak tersangka untuk menuntut pelaksanaan kewajiban tersebut.

Kesimbangan perumusan antara kewajiban penyidik dan hak tersangka, sesungguhnya sudah terjadi dalam KUHAP, antara lain dalam perumusan ketentuan yang mengatur tentang kewajiban yang harus dilakukan penyidik pada saat melakukan penangkapan dan penahanan.

Dalam hal penahanan, KUHAP secara tegas dan jelas menggariskan kewajiban penyidik saat penangkapan, sebagaimana diatur di dalam Pasal 18, yang selengkapnya menggariskan bahwa:

Pasal 18:

(1) Pelaksanaan tugas penangkapan dilakukan oleh petugas kepolisian negara Republik Indonesia dengan memperlihatkan surat tugas serta memberikan kepada tersangka surat perintah penangkapan yang mencantumkan identitas tersangka dan menyebutkan 
alasan penangkapan serta uraian singkat perkara kejahatan yang dipersangkakan serta tempat ia diperiksa.

(2) Dalam hal tertangkap tangan penangkapan dulakukan tanpa surat perintah, dengan ketentuan bahwa penangkap harus segera menyerahkan tertangkap beserta barang bukti yang ada kepada penyidik atau penyidik peinbantu yang terdekat.

(3) Tembusan surat perintah penangkapan sebagaimana dimaksud dalam ayat (1) harus diberikan kepada keluarganya segera setelah penangkapan dilakukan.

Demikian pula halnya dengan penahanan, KUHAP menyatakan kewajiban penyidik di dalam Pasal 21 yang menyatakan sebagai berikut:

Pasal 21:

(1) Perintah penahanan atau penahanan lanjutan dilakukan terhadap seorang tersangka atau terdakwa yang diduga keras melakukan tindak pidana berdasarkan bukti yang cukup, dalam hal adanya keadaan yang menimbulkan kekhawatiran bahwa tersangka atau terdakwa akan melarikan diri, merusak atau menghilangkan barang bukti dan atau mengulangi tindak pidana.

(2) Penahanan atau penahanan lanjutan dilakukan oleh penyidik atau penuntut umum terhadap tersangka atau terdakwa dengan memberikan surat perintah penahanan atau penetapan hakim yang mencantumkan identitas tersangka atau terdakwa dan menyebutkan alasan penahanan serta uraian singkat perkara kejahatan yang dipersangkakan atau didakwakan serta tempat ia ditahan.

(3) Tembusan surat perintah penahanan atau penahanan lanjutan atau penetapan hakim sebagaimana dimaksud dalam ayat (2) harus diberikan kepada keluarganya.

(4) Penahanan tersebut hanya dapat dikenakan terhadap tersangka atau terdakwa yang melakukan tindak pidana dan atau percobaan maupun pembenian bantuan dalam tindak pidana tersebut dalam hal:

a. tindak pidana itu diancam dengan pidana penjara lima tahun atau lebih;

b. tindak pidana sebagaimana dimaksud dalam Pasal 282 ayat (3), Pasal 296, Pasal 335 ayat (1), Pasal 351 ayat (1), Pasal 353 ayat (1), Pasal 372, Pasal 378, Pasal 379 a, Pasal 453, Pasal 454, Pasal 455, Pasal 459, Pasal 480 dan Pasal 506 Kitab Undang-undang Hukum Pidana, Pasal 25 dan Pasal 26 Rechtenordonnantie (pelanggaran terhadap ordonansi Bea dan Cukai, terakhir diubah dengan Staatsblad Tahun 1931 Nomor 471), Pasal 1, Pasal 2 dan Pasal 4 Undang-undang Tindak Pidana Imigrasi (Undang-undang Nomor 8 Drt. Tahun 1955, Lembaran Negara 
Tahun 1955 Nomor 8), Pasal 36 ayat (7), Pasal 41, Pasal 42, Pasal 43, Pasal 47, dan

Pasal 48 Undangundang Nomor 9 Tahun 1976 tentang Narkotika (Lembaran Negara Tahun 1976 Nomor 37, Tambähan Lembaran Negara Nomor 3086).

Merujuk pada ketentuan Pasal 18 dan Pasal 21 KUHAP di atas, dapat dilihat dengan jelas hal-hal apa saja yang menjadi kewajiban penyidik pada saat melakukan penangkapan dan penahanan. Kewajiban dimaksud antara lain memperlihatkan surat tugas serta memberikan kepada tersangka surat perintah penangkapan yang mencantumkan identitas tersangka dan menyebutkan alasan penangkapan serta uraian singkat perkara kejahatan yang dipersangkakan serta tempat ia diperiksa. Pada saat penahanan, penyidik berkewajiban menyerahkan surat perintah penahanan atau penetapan hakim yang mencantumkan identitas tersangka atau terdakwa dan menyebutkan alasan penahanan serta uraian singkat perkara kejahatan yang dipersangkakan atau didakwakan serta tempat ia ditahan. Disamping itu, penyidik berkewajiban pula menyerahkan tembusan surat perintah penangkapan atau penahanan kepada keluarganya.

Terhadap kewajiban penyidik yang dinyatakan secara jelas dan tegas di dalam kedua Pasal di atas, diimbangi dengan hak tersangka untuk menguji apakah kewajiban yang menjadi amanat KUHAP tersebut telah benar-benar dipenuhi oleh penyidik, sehingga upaya paksa berupa penangkapan dan penahanan tersebut menjadi absah secara hukum.

Hak untuk menguji keabsahan penangkapan dan penahanan tersebut, diatur di dalam Bab X Bagian Kesatu tentang Pra Peradilan, yang mencakup Pasal 77 sampai dengan Pasal 83 KUHAP. Di dalam Pasal 77 sampai dengan Pasal 79 KUHAP diatur mengenai pemeriksaan keabsahan penangkapan dan penahanan, yang selengkapnya digariskan bahwa:

Pasal 77:

Pengadilan negeri berwenang untuk memeriksa dan memutus, sesuai dengan ketentuan yang diatur dalam undang-undang ini tentang:

a. sah atau tidaknya penangkapan, penahanan, penghentian penyidikan atau penghentian penuntutan;

b. ganti kerugian dan atau rehabilitasi bagi seorang yang perkara pidananya dihentikan pada tingkat penyidikan atau penuntutan.

Pasal 78:

(1) Yang melaksanakan wewenang pengadilan negeri sebagaimana dimaksud dalam Pasal 77 adalah praperadilan. 
(2) Praperadilan dipimpin oleh hakim tunggal yang ditunjuk oleh ketua pengadilan negeri dan dibantu oleh seorang panitera.

Pasal 79:

Permintaan pemeriksaan tentang sah atau tidaknya suatu penangkapan atau penahanan diajukan oleh tersangka, keluarga atau kuasanya kepada ketua pengadilan negeri dengan menyebutkan alasannya.

Merujuk pada ketentuan KUHAP yang mengatur tentang kewajiban penyidik dalam penangkapan dan penahanan, dan hak seorang tersangka untuk menguji keabsahan penangkapan dan penahanan terhadap dirinya melalui mekanisme Pra Peradilan, kiranya dapat menjadi pertimbangan untuk diadopsi dalam merumuskan ketentuan yang sama terhadap kewajiban penyidik memberikan kesempatan kepada tersangka, menghubungi dan minta bantuan penasihat hukum untuk mendampinginya, sejak terhadap si tersangka itu dilakukan penangkapan.

Agar proses penyidikan bebas dari intimidasi, kekerasan dan penyiksaan, demi tegaknya proses hukum yang adil, sebagai tonggak sebuah negara yang berdasarkan hukum, penelitian ini merekomendasikan untuk melakukan perubahan mendasar dalam perumusan ketentuan KUHAP terutama tentang peran dan peran Penasihat Hukum dalam pemenuhan hak-hak pelanggar hukum.

Sehubungan dengan perubahan perumusan ketentuan KUHAP mengenai peran dan peran Penasihat Hukum tersebut, penelitian ini merekomendasikan 3 (tiga) hal sebagai berikut:

1.) Penempatan kewajiban memberikan kesempatan kepada tersangka, menghubungi dan minta bantuan penasihat hukum, untuk mendampinginya sejak ditangkap, pada pasal khusus. Atau Pemindahan ketentuan dimaksud dari asas-asas KUHAP, ke dalam pasal tersendiri;

2.) Apabila tersangka menghendaki didampingi Penasehat Hukum, maka kehadiran Penasihat Hukum menjadi syarat sah penangkapan;

3.) Memperluas ketentuan yang mengatur tentang Pra Peradilan, dengan mencantumkan kehadiran Penasihat Hukum pada saat penangkapan sebagai salah satu aspek yang dapat diuji keabsahannya melalui sidang Pra Peradilan.

\section{E. Kesimpulan}


Berdasarkan uraian pada bab terdahulu, maka dapat diambil beberapa kesimpulan sebagai berikut:

1. Peran Penasihat Hukum, diatur di dalam Undang-Undang Advokat dan KUHAP. Di dalam Undang-Undang Advokat ditegaskan bahwa Penasihat Hukum adalah penegak hukum yang mempunyai peran setara dengan penegak hukum lainnya dalam menegakkan hukum dan keadilan. Terkait dengan penyidikan yang bebas dari intimidasi, kekeras-an dan penyiksaan, KUHAP mengamanatkan bahwa penyidik wajib memberikan kesempatan kepada tersangka, menghubungi dan minta bantuan penasihat hukum untuk mendampinginyasejak penangkapan. Namun ketentuan KUHAP tersebut, dalam praktiknya hampir tidak pernah dilaksanakan. Hal itu terjadi karena adanya kekosongan norma di dalam KUHAP, yang mengatur tentang akibat hukum bagi penyidik dan penyidikan perkara bersangkutan, yang mengabaikan kewajiban dimaksud. Ketiadaan hal itu berpotensi menimbulkan penyalah-gunaan kekuasaan oleh penyidik, dengan melakukan kekerasan demi memperoleh keterangan "yang diinginkan" dari seorang tersangka. Tindakan penyidik yang demikian, akan menciderai hakekat penegakan hukum yakni terciptanya proses hukum yang adil (due process of law).

2. konsepsi pembaharuan hukum acara pidana tentang peran Penasihat Hukum dalam penyidikan, sehingga mampu menciptakan penyidikan yang bebas dari kekerasan dan penyiksaan demi tercapainya hakikat penegakan hukum yakni proses hukum yang adil, yakni terciptanya due process of law, yang ditandai dengan proses penyidikan bebas dari intimidasi, kekerasan dan penyiksaan, direkomendasikan untuk melakukan perubahan mendasar dalam perumusan ketentuan KUHAP terutama tentang peran dan peran Penasihat Hukum dalam pemenuhan hak-hak pelanggar hukum.

\section{F. Rekomendasi}

Berdasarkan kesimpulan di atas, maka dapat direkomendasikan beberapa saran sebagai berikut:

1. Agar kekosongan norma (vacuum of norm) di dalam perundang-undangan pidana Indonesia dapat diatasi, maka harus dilakukan perubahan perumusan ketentuan KUHAP mengenai peran Penasihat Hukum. Untuk itu direkomendasikan 3 (tiga) hal sebagai berikut: 
a. Penempatan kewajiban memberikan kesempatan kepada tersangka, menghubungi dan minta bantuan penasihat hukum, untuk mendampinginya sejak ditangkap, pada pasal khusus. Atau Pemindahan ketentuan dimaksud dari asas-asas KUHAP, ke dalam pasal tersendiri;

b. Apabila tersangka menghendaki didampingi Penasehat Hukum, maka kehadiran Penasihat Hukum menjadi syarat sah penangkapan;

c. Memperluas ketentuan yang mengatur tentang Pra Peradilan, dengan mencantumkan kehadiran Penasihat Hukum pada saat penangkapan sebagai salah satu aspek yang dapat diuji keabsahannya melalui sidang Pra Peradilan.

2. Agar penerapan konsepsi proses penyidikan yang bebas dari intimidasi, kekerasan dan penyiksaan, benar-benar dapat diwujudkan, maka kepada pihak yang 1 mpeten terhadap program legislasi nasional, direkomendasikan untuk segera muakukan pembaharuan KUHAP, sebagai payung hukum acara pidana nasional.

\section{G. Daftar Pustaka}

Adnan Buyung Nasution, Bantuan Hukum, Akses Masyarakat Marginal Terhadap Keadilan (Tinjauan, Sejarah, Konsep, Kebijakan, Penerapan dan Perbandingan di Berbagai Negara), Lembaga Bantuan Hukum Jakarta, 2007

Yudha Pandu, Klien \& Advokat Dalam Praktek, PT. Abadi, Jakarta, 2004

Telly Sumbu, Merry E. kalalo, Engelien R. Palandeng dan Johny Lumolos,..Kamus Umum Politik dan Hukum, Jala Permata Aksala, Jakarta, 2010.

Suhrawardi K Lubis, Etika Profesi Hukum, Sinar Garfika, Jakarta, 2012. 